INTERNATIONAL JOURNAL OF RESEARCHES IN BIOSCIENCES, AGRICULTURE AND TECHNOLOGY (c) VISHWASHANTI MULTIPURPOSE SOCIETY (Global Peace Multipurpose Socie ty) R. No. MH-659/13(N) www.vmsindia.org

\title{
PHYSIOLOGICAL AND BIOCHEMICAL CHANGES IN ARHAR SEEDS DUE TO INFESTATION OF BRUCHID DURING STORAGE
}

\author{
Rajesh Gadewar ${ }^{1}$, Ashish Lambat ${ }^{2}$, Vipin Babhulkar ${ }^{3}$, \\ Prachi Lambat ${ }^{4}$, Ramesh Parate ${ }^{5}$ and Sanjiv Charjan 6 \\ 1,2Sevadal Mahila Mahavidyalaya and Research Academy, Nagpur (MS) \\ 3,5,6 Dr. PDKV's Colle ge of Agricultu re, Nagpur. \\ ${ }^{4}$ Shri Mathu radas Mohata Science College, Nagpur
}

Abstract:

Arhar is an important sources of protein. The seed infestation by pulse bee tle during storage is a major problem. This pape $r$ gives a brief account of certain Physical, Physiological, Biochemical and Mycologicalchanges in qualities of Arhar seeds due to infestation of pulse beetle during storage. In the present study, it was found that the percentage of moisture content, total ash, crude fiber, crude prote in significantly increased and crude fat total carbohydrate, total sugar pulse beetle reducing sugar and non-reducing sugar significantly decreased in pulse bee tle infested seeds of Arhar during storage. Increase in prote in content is attributed to insect metabolites like uric acid, which is nitrogenous is nature. The incidence percentage of fungi such as species of Alternaria, Aspergillus, Curularia, Fusarium Peniciliumand Rhizopuswere predominant over all other fungi on infested Bengal gram seeds and it is increased with increase in pulse beetle infestation during storage. The physical and physiological qualities of Arhar seeds i.e. 100-seed weight, germination, seedling vigour and field emergence percentage decreased with increase in infestation of pulse beetle during storage

Keywords : Arhar, Bruchid, infestation, seed quality and storage.

\section{Introduction:}

Pulses are the most important source of prote in in Indian diet. Storage of pulse seeds is a major problem and it is estimated that about $10 \%$ of stored pulse seeds are lost due to biological factors of which insects and rodents alone account of $5 \%$. In severe cases the infe station was observed to be about $90 \%$. Pulse beetles of various species belong to the family Bruchidae are important insect pest attacking variety of pulses in store. Adult female stick their eggs on the pulse seeds and the emerging grubs and bore into the seeds. The grubs remain inside the seed and appearance of a capped exit hole on the seed indicates the pupil stage. After a few days the adult emerges from the seed. About one month is required to comple te one generation.

The stored grain insect's pest's infestation also encourages fungus growth by increasing the moisture content of the seeds which decreased the quality and viability of the seeds. Chris te nsen and Kaufmann (1969) reported that the fungal pathogen associated with stored seed are chiefly responsible for seed de te rioration and reduction in germination potential. Apart from this the seedling vigour is also adversely affected. Among the storage fungi species, many were well known toxin producers. The present work was carried out to investigate the post harvest losses in qualities of Arhar seeds due to pulse beetle infestation.

\section{Material and Methods:}

Arhar freshly threshed seeds by multi crop thresher which were then cleaned and sieved with 10/64 inch $(3.96 \mathrm{~mm})$ diameter sieve to remove small fraction of seeds or insects produced in 2013-2014. The seeds were dried up to the safe moisture level $(10 \pm 1 \% \mathrm{wb})$ The experiment conducted in glass bottle of two litre capacity. The glass bottle was then filled with 1,000 grams of Arhar cv. C-1 1seeds. There were four replications. Ten pairs of 2-3 days old pulse beetle (Callosobruchus analis) were released in glass bottles covered with muslin cloth. The set of experiment was kept in well ventilated wire mesh almirah in mesonary building having cemented walls, roof and floor under ambient temperature $\left(10.2\right.$ to $\left.46{ }^{\circ} \mathrm{C}\right)$ and relative humidity (27 to 80\%) from January 2014 to June 2014. For determination of physical, physiological, biochemical and mycological changes in stored seeds of Arhar were observed at interval of 3 months. The initial observations also taken at the start of experiment. The physical qualities of Arhar seeds i.e. seed infestation percentage, moisture content and 100 seeds weight were studied. 100 seed weight was tested in quadruplicated with 100 seeds in each replication. The infested seeds we counted and total damaged seeds were reported in percentage. Moisture percentage was estimated according to International rule for seed testing (Anon. 1985). The physiological qualities of Arhar seeds i.e. seed germination; seeding vigour and field emergence were studied. The germination percentage was evaluated on the value for percent normal seedlings (Anon. 1985). The seedling vigour index was worked our following the method of Abdul-Baki and 
Anderson (1973. For field emergence test, sowing of Arhar seeds was done in randomized block design with four replications with inter and intra-row spacing of 1 feet and 6 inches respectively. Observations for field emergence were recorded daily and finally the established seedlings were counted after one month of sowing.

To assess the biochemical qualities of the seeds of Arhar i.e. protein, fat, total ash, crudefibre, reducing and non-reducing sugars according to the standard procedures of A.A.C.C. (Anon., 1962). Values for carbohydrate and total sugar were calculated (Joslyn, 1970) The fungal flora of the seeds were detected by the standard moist blotter and agar medium techniques as prescribed by I.S.T.A. (Anon., 1976) the different types of fungal growth on the seeds were expressed in percentage. The experimental data was statistically scrutinized as per Panse and Sukhatme, 1967. (The experiment needed more treatment to compare, should divide ages of pulse beetles or make some method to protect seeds).

\section{Result and Discussion:}

It was observed from the Table 1 that the moisture content of the seeds increased with increasing the storage periods i.e. 3 months $(10.91 \%)$ and 6 months $(12.26 \%)$. A significant increase in moisture content was observed this might be due to the activities of pulse beetles on seeds during storage. Similar observation also reported by Shrivastava et al. (1989). Gadewar et al. (2011) Seed damage is increased with increasing the storage periods of 3 months $(25.10 \%)$ and 6 months $(59.28 \%)$ respectively. Charjan et al. (2006) and Gadewar et al. (2011) reported that the infestation of pulse beetles increased with increasing the storage periods. The 100-seed weight of seed decreases with increasing the storage periods. Similar observation also reported by Charjan (1995). Similarly the germination, seedling vigour and field emergence \% decreases with increasing the storage periods. In costal region of Andhra Pradesh percent germinability of Bengal gram was found to decrease from $81 \%$ to $65 \%$ within 4 months of storage (Vimla and Pushpamma, 1993). Charjan and Tarar (1994) and Gadewar et al. (2011) reported that the germination percentage, seedling vigour and field emergence percentage decreases with increasing storage periods in moth bean and pigeon pea infe sted by pulse beetles during storage.

Table 1; Effect of pulse beetle infestation on physical, physiological, bioche mical and mycological qualities of Arhar during s torage.

\begin{tabular}{|c|c|c|c|c|}
\hline & Seed Quality parameters & Initial & After 3 months & After 6 months \\
\hline A & $\begin{array}{l}\text { Physical seed quality } \\
\text { 1. Seed mois ture (\% wb) } \\
\text { 2. Seed damage }(\%) \\
\text { 3. } 100-\text { seed weight }(\mathrm{gm})\end{array}$ & $\begin{array}{l}10 \\
0.00 \\
10.12\end{array}$ & $\begin{array}{l}10.7 \\
23.9 \\
8.5\end{array}$ & $\begin{array}{l}12 \\
54.7 \\
7.4\end{array}$ \\
\hline B & $\begin{array}{l}\text { Physiological seed quality } \\
\text { 1. Germination (\%) } \\
\text { 2. Seed ling Vigour Index (SVI) } \\
\text { 3. Field e mergence (\%) }\end{array}$ & $\begin{array}{l}92 \\
4109 \\
82\end{array}$ & $\begin{array}{l}82 \\
3019 \\
72\end{array}$ & $\begin{array}{l}56 \\
2102 \\
52\end{array}$ \\
\hline C & $\begin{array}{l}\text { Biochemical seed quality } \\
\text { 1. Total ash }(\%) \\
\text { 2. Crude fibre }(\%) \\
\text { 3. Crude Prote in }(\%) \\
\text { 4. Crude fat } \\
\text { 5. Total carbohydrate } \\
\text { 6. Total sugar }(\%) \\
\text { 7. Reducing sugar }(\%) \\
\text { 8. Non-re ducing sugar }\end{array}$ & $\begin{array}{l}4.81 \\
8.1 \\
23.08 \\
3.0 \\
72.1 \\
8.9 \\
13.0 \\
8.1\end{array}$ & $\begin{array}{l}5.41 \\
8.9 \\
25.08 \\
2.9 \\
68.9 \\
7.9 \\
10.1 \\
7.5\end{array}$ & $\begin{array}{l}6.21 \\
9.3 \\
28.9 \\
2.0 \\
62.4 \\
6.8 \\
2.1 \\
5.9\end{array}$ \\
\hline D & $\begin{array}{l}\text { Mycological observation } \\
\text { 1. Alternaria sp. }(\%) \\
\text { 2. Aspergillus sp. }(\%) \\
\text { 3. Curvualaria sp. }(\%) \\
\text { 4. Fusarium sp. }(\%) \\
\text { 5. Penicullium } \mathrm{sp} .(\%) \\
\text { 6. Rhizopus sp. }(\%) \\
\text { 7. Total incidence }(\%)\end{array}$ & $\begin{array}{l}8.50 \\
2.50 \\
1.50 \\
0.50 \\
0.00 \\
0.00 \\
13.00\end{array}$ & $\begin{array}{l}5.75 \\
8.75 \\
4.25 \\
5.25 \\
3.75 \\
3.25 \\
31.00 \\
\end{array}$ & $\begin{array}{l}3.75 \\
20.25 \\
18.25 \\
10.75 \\
10.25 \\
9.75 \\
73.00 \\
\end{array}$ \\
\hline
\end{tabular}


Pulse beetle feeds on the cotyledonous portion of the Bengal gram seed leaving the seed coat intact and that is one reason that higher values for crude fibre and total ash have been obtained in infested seed, as seed coat is rich in crude fibre and minerals (Singh et al. 1968 and Shrivastava et al. 1989). Increase in protein content is attributed to insect metabolites like uric acid, which is nitrogenous in nature (Shrivastava et al. 1989). Increase in reducing sugars and decreasing in non-reducing sugars has been shown in stored Bengal gram seeds. Similar results have been reported by Khare (1972), Shrivastava et al. (1989) Gadewar et al. (2011) Charjan and Tarar (1994). The following fungi were found to be associated with stored seeds of Arhar. The present pulse beetles damaged seeds yielding a particular fungus viz., Alternaria sp., Aspergillus sp., Curvualaria sp., Fusarium sp., Penicillium sp. and Rhizopus sp. irrespective of storage periods. In the present study, the incidence percentage of storage fungi increases with increasing seed damages by pulse beetles and storage periods. The results are in conformity with the results of Charjan et al. (2006) and Gadewar et al. (2011)

Thus from the present study, it can be concluded that infestation of pulse beetle in Arhar increases the moisture content which is favorable for multiplication of fungal flora and decreases the 100-seed weight, germinability, seedling vigour and field emergence percentage of seeds during storage. It also observed that the decrease of the crude fat, total carbohydrates and total sugars and increase of total ash, crude fibre and crude protein in infested Arhar. Increase in protein content is attributed to insect metabolites like uric acid, which is nitrogenous in nature. The percentage of storage fungi increases with increasing pulse beetles damage and storage period. Among the identified fungi species, many were well known toxin producers. The pulse beetle infested Arhar seeds should be avoided for sowing or consumption purposes.

\section{References:}

Abdul Baki, A. A. and Anders on, A.A. 1973. Vigour determination in soybean seed by multiple criteria. Crop Science. 13: 630-633.

Charjan, S.K.U. 1995. Efficacy of Acorus calamus L.rhizome powder against the pulse beetle, Callosobruchus chinensis L. infested stored pige on pea (Cajanuscajan). In : Herbal, medicine, biodiversity and conse rvation strategies (Ed. Rajak and M.K.Rai) Inte rnational Book Distributor, Deharadun: 242-246.

Charjan, S.K.U. and Tarar, J. L. 1994. Biochemical changes in jowar grains due to infestation of rice weeil and khaprabeetel during storage proceeding National Academy of Science. 64 (B) IV: 381-384.

Charjan, S.K.U., Wankhede, S.R. and Jayade, K.G. 2006. Viability, vigour and mycoflora changes in pulse beetle (Callosobruchus sp.) damaged seeds of cowpea produced in dryland condition. In: Economics of sustainability of dryland agriculture, Nagpur: 5-6.

Cristensen, C.M. and Kaufmann, H.H. 1969. Grain Storage- the role of fungi in quality loss.153 pp. Univ. of Minnesola Press, Minneapolis.

Gadewar, R., A. Lambar, S.Charjan, P. Charde, K. Cherian and P. Lambat.2011 Post harvest losses in qualities of pigeon pea due to pulse beetle infesttion. In: Proc. International conference in Agricultural engineering. Chonburi, Thailand Page No.C/45-51.

AACC. 1962. Approved methods of American Association of Cereal Chemist, $8^{\text {th }}$ rev. ed. St. Paul (Minnesota)

IST A. 1976. International rules for seed testing. Seed Sci. and Technol. 4: 108

IST A. 1985. International rules for seed testing . Seed Sci. and Technol. 13: 299-513.

Joslyn, M.A. 1970. Me thods of food analysis: Physical, chemical and instrumental methods of analysis. Academic Press, New York: 845.

Khare, B.P. 1972. Insect pest of stored grain and the ir control in Uttar Pradesh.Research Bulletin. No. 5 G.B.U.A.T., Pan thagar: 132-139.

Panse, V.G. and Sukhatme, P.V. 1967. Statistical methods for agril Workers, I.C.A.R. Publication, New Delhi.

Shrivastava, S., Gupta, K.C. and Agrawal, A. 1989. Japanese mint oil as fumigant and its effect on insect infestation, nutritive value and germinability of pige on pea seed during storage. Seed Res. 17 (1) : 96-98.

Singh, S., Singh, H.D. and Sikka, K.C. 1968. Distribution of nutrients in anatomical parts of common Indian pulses. Cereal Chem. 45: 13-18.

Vimla, V. and Pushpamma, P. 1983. Storage quality of pulses stored in three agroclimatic regions of Andhra Pradesh II. Viability Changes. Bull. Grain 21(3):

217-22. 